\title{
Hubungan antara infeksi Soil Transmitted Helminth dengan kejadian atopi pada anak sekolah dasar di wilayah kerja Puskesmas Lubuk Buaya Kota Padang
}

Fajria Khalida ${ }^{1}$, Selfi Renita Rusjdi ${ }^{2}$, Yusrawati ${ }^{3}$

\begin{abstract}
Abstrak
Infeksi Soil Transmitted Helminth dan atopi merupakan penyakit yang sering terjadi pada anak sekolah dasar. Penyakit cacingan lebih sering terjadi di negara berkembang dan daerah pedesaan dengan higiene dan sanitasi yang buruk, sedangkan penyakit atopi meningkat di negara maju dan daerah perkotaan dengan higiene dan sanitasi yang baik. Beberapa penelitian menunjukkan hasil bahwa adanya proteksi dari penyakit kecacingan terhadap atopi. Tujuan: Mengidentifikasi hubungan antara infeksi STH dan kejadian atopi pada anak SD di wilayah kerja Puskesmas Lubuk Buaya Kota Padang. Metode: Penelitian ini mengunakan desain cross sectional yang dilakukan pada bulan Februari sampai Maret 2019. Subjek penelitian merupakan siswa kelas 1,2, dan 3 SD Negeri 06 Pasir Jambak, SD Negeri 31 Pasir Kandang, dan SD Negeri 23 Pasir Sebelah. Sampel berjumlah 61 siswa yang dipilih secara Stratified Random Sampling. Subjek penelitian mengumpulkan sampel feses dan orang tua subjek penelitian mengisi kuesioner ISAAC secara terbimbing. Infeksi STH dinilai secara mikroskopik dengan melakukan pemeriksaan feses menggunakan metode Kato Katz untuk melihat telur cacing, dan kejadian atopi dilihat dari kuesioner ISAAC yang diisi oleh orang tua. Data dianalisis menggunakan uji Chi-square. Hasil: Menunjukkan 24,6\% subjek penelitian terinfeksi cacing dan $18 \%$ subjek penelitian mempunyai penyakit alergi. Infeksi yang terjadi paling banyak merupakan infeksi campuran Ascaris lumbricoides disertai Trichuris trichiura dengan intensitas ringan-sedang. Simpulan: Tidak terdapat hubungan yang bermakna antara infeksi STH dengan kejadian atopi $(p=0,712)$.
\end{abstract}

Kata kunci: Infeksi STH, kejadian atopi, anak

\section{Abstract}

Soil Transmitted Helminth infection and atopy are common problems in elementary children. STH infection more common in developing countries and rural area with poor hygiene and sanitation, but atopy increases in developed countries and urban area with good hygiene and sanitation. Several studies have reported that helminth infections are presumed to be protective against allergic diseases. Objectives: To identified the relationship between the infection of STH and atopy incidence in children of elementary school in the area of Lubuk Buaya Health Center Padang. Methods: This study used a cross sectional design in February until March in 2019. Subject of this research is children grade I,II and III at SD Negeri 06 Pasir Jambak, SD Negeri 31 Pasir Kandang, dan SD Negeri 23 Pasir Sebelah, sixty students were chosen as samples by using stratified random sampling method. Stool sample from research subjects were collected and their parent filled ISAAC questionnaires. Stool samples were examined microscopically with Kato Katz method to find the eggs of the helminth, and status of atopy examined by ISAAC questionnaire that filled by parents. Data were analyzed by using the Chi-Square test. Results: $24,6 \%$ of the research subjects were infected by STH and $18 \%$ of the research subjects have atopy disease. Most infections was mixed infections of Ascaris lumbricoides and Trichuris trichiura with mild-moderate intensity. Conclusion: There is no relationship between STH infection and atopy incidence ( $p=0,712)$.

Keywords: soil transmitted helminth, the incidence of atopy, children 
Affiliasi penulis: 1. Prodi Penddikan Dokter, Fakultas Kedokteran, Universitas Andalas, Padang, Indonesia. 2. Bagian Parasitologi, Fakultas Kedokteran, Universitas Andalas, Padang, Indonesia. 3. Bagian Obstetri dan Ginekologi, Fakultas Kedokteran, Universitas Andalas, Padang, Indonesia.

Korespondensi: Selfi Renita Rusjdi, Email:

drselfirenita.rusjdi@gmail.com Telp: 082284913537

\section{PENDAHULUAN}

Infeksi Soil-Transmitted Helminth (STH) merupakan salah satu infeksi yang umum di dunia. Infeksi ini ditularkan melalui tanah yang terkontaminasi oleh feses manusia yang terinfeksi. ${ }^{1}$ Lingkungan yang beriklim tropis dan memiliki kelembaban yang tinggi mendukung perkembangan dari cacing usus terutama STH seperti cacing gelang (Ascaris lumbricoides), cacing cambuk (Trichuris trichiura) dan cacing tambang (Necator americanus dan Ancylostoma duodenale). ${ }^{2}$

Data World Health Organization menunjukkan lebih dari 1,5 miliar orang, atau $24 \%$ dari populasi dunia terinfeksi cacing ini. ${ }^{3}$ Prevalensi penyakit kecacingan di Indonesia pada umumnya masih sangat tinggi, yaitu berkisar antara 10-85,9\% terutama pada golongan penduduk kurang mampu dengan sanitasi yang buruk. ${ }^{4}$

Data Dinas Kesehatan Kota Padang pada tahun 2014 menunjukkan angka kejadian penyakit kecacingan masih cukup tinggi, yaitu ditemukan jumlah kasus kecacingan sebanyak 1250 kasus. Berdasarkan data tersebut, didapatkan bahwa di antara 22 puskesmas yang ada, prevalensi penyakit kecacingan tertinggi berada di wilayah puskesmas Lubuk Buaya yaitu sebanyak 249 kasus. $^{5}$

Beberapa penelitian menunjukkan bahwa infeksi Soil Transmitted Helminth lebih sering terjadi pada anak usia Sekolah Dasar. Kondisi ini disebabkan karena masih rendahnya respon imun serta didukung oleh perilaku yang tidak sesuai dengan standar kesehatan. ${ }^{6}$ Infeksi cacing ini sering terjadi pada anak-anak yang tinggal di daerah pedesaan dengan iklim tropis dan memiliki akses sanitasi dan air bersih yang buruk. ${ }^{7}$ Penularan cacing pada anak usia SD sering terjadi melalui kontaminasi makanan akibat telur cacing, jarang menggunakan alas kaki, dan kuku yang panjang serta kotor. $^{2}$

Atopi adalah kecendrungan genetik dalam keluarga untuk terjadinya hipersensitivitas kulit dan membran mukosa terhadap bahan dalam lingkungan yang disertai dengan peningkatan produksi IgE dan atau perubahan reaktivitas nonspesifik, yang menimbulkan penyakit alergi seperti konjungtivitis, asma, dermatitis atopik, dan rinitis alergi. ${ }^{8}$ Insiden atopi dan penyakit alergi mengalami peningkatan menjadi dua kali lipat dalam dekade terkahir, terutama di negara maju dengan sosio ekonomi tinggi. ${ }^{9}$ Puskesmas Lubuk Buaya Kota Padang melaporkan jumlah kasus penyakit atopi pada tahun 2018 sebanyak 456 kasus. $^{10}$

Paparan agen infeksi dalam tubuh seseorang berpengaruh terhadap respon imunnya, terutama pada keseimbangan $T$ helper 1 (Th1) dan $T$ helper 2 (Th2). Pada negara berkembang, paparan terhadap agen infeksi ini sering terjadi dan berlangsung secara kronik. Hal ini berpengaruh terhadap aktivasi dari sel Th1, sehingga respon imun tubuh tidak mengarah kepada Th2 yang merupakan dasar terjadinya penyakit alergi. Namun, terjadi pengecualian pada infeksi cacing yang menimbulkan respon imun yang sama dengan penyakit alergi, yaitu mengarah ke Th2. Pada negara yang termasuk daerah maju dan juga daerah perkotaan, paparan terhadap agen infeksi telah banyak berkurang. $\mathrm{Hal}$ ini didukung oleh higienitas yang bagus dan penggunaan vaksin dan antibiotik yang sering. Keadaan ini menyebabkan kurangnya aktivasi dari sel Th1 dan respon imun tubuh lebih mengarah ke Th2 yang ditandai dengan peningkatan $\lg E$ terhadap alergen, mastositosis dan eosinofilia. Proses ini akan mengakibatkan reaksi inflamasi yang muncul berupa peningkatan produksi mukus, peningkatan kontraksi otot polos serta memicu reaksi alergi pada saluran napas. ${ }^{11,12}$

Berdasarkan uraian diatas, dapat dilihat bahwa sistem imun yang berperan dalam infeksi cacing memiliki kesamaan dengan atopi, dimana pada keduanya akan terjadi peningkatan dari eosinofil, Immunoglobulin $E$ dalam serum, basofil dan sel mast dalam jaringan yang memungkinkan terjadinya respon hipersensitivitas tipe cepat. ${ }^{13}$ Meskipun memiliki respon imun yang sama, ternyata infeksi cacing dapat memproteksi seseorang dari penyakit alergi. Hal ini terjadi akibat aktivitas regulatory network yang sering terjadi pada infeksi cacing kronik dan dapat menekan reaksi alergi. ${ }^{11}$

Infeksi cacing tidak lagi menjadi masalah kesehatan masyarakat di negara-negara maju karena berhasilnya program pengendalian, diantaranya yaitu 
program sanitasi lingkungan yang baik, dan penyediaan obat antihelmentik yang efektif. Sebaliknya, penyakit atopi mengalami peningkatan terutama di negara maju dengan sosio ekonomi yang tinggi. ${ }^{9}$

Pada beberapa penelitian menunjukkan bukti terdapatnya hubungan terbalik antara infeksi parasit dan penyakit atopi. Berdasarkan penelitian Andiarsa et al pada tahun 2013 didapatkan hasil bahwa populasi yang mengalami atopi cenderung lebih banyak pada populasi yang tidak menderita infeksi cacing, sedangkan populasi yang menderita infeksi cacing justru lebih banyak terjadi pada populasi yang tidak atopi. ${ }^{14}$

Kelurahan Pasia Nan Tigo berada di wilayah kerja Puskemas Lubuk buaya. Letak geografis daerah ini berada dekat dari pantai, selain itu didapatkan pemukiman masyarakat yang kumuh, serta kebiasaan buang air besar di sepanjang pantai, sehingga menjadikan tempat ini sangat cocok untuk penyebaran infeksi STH. Terdapat tiga SD yang berada di daerah ini, diantaranya yaitu SDN 06 Pasir Jambak, SDN 23 Pasia Sabalah dan SDN 31 Pasia Kandang.

Berdasarkan uraian diatas, maka perlu dilihat bagaimana hubungan antara Infeksi Soil Transmitted Helminth (STH) dengan kejadian atopi pada anak Sekolah Dasar di wilayah kerja Puskesmas Lubuk Buaya Kota Padang.

\section{METODE}

Penelitian ini adalah studi analitik dengan pendekatan cross-sectional untuk mengetahui hubungan antara Infeksi Soil Transmitted Helminth (STH) dengan kejadian atopi pada anak Sekolah Dasar di wilayah kerja Puskesmas Lubuk Buaya Kota Padang. Variabel independen adalah infeksi STH, variabel dependen adalah kejadian atopi. Penelitian ini dilakukan di Laboratorium Parasitologi Fakultas Kedokteran pada bulan Februari hingga Maret 2019.

Populasi penelitian ini adalah siswa kelas 1 sampai 3 SDN 06 Pasir Jambak, SDN 23 Pasia Sabalah dan SDN 31 Pasia Kandang. Sampel penelitian adalah bagian dari populasi yang memenuhi kriteria inklusi. Kriteria inklusi penelitian ini adalah siswa yang bersedia menjadi responden dan siswa yang mendapatkan persetujuan dari orang tua. Pengambilan sampel menggunakan teknik Proportionate Stratified Random Sampling. Jumlah sampel yang diperlukan adalah 61 orang.

Data diperoleh dengan cara mengumpulkan data responden melalui kuesioner dan pot yang berisi tinja. Data dianalisis menggunakan program software statistik pada komputer yaitu dianalisis secara univariat dan bivariat. Analisis univariat dilakukan untuk melihat distribusi frekuensi dari masing-masing variabel. Analisis bivariat dilakukan untuk menganalisis hubungan antara variabel independen dan variabel dependen. Hubungan dua variabel tersebut dianalisis dengan menggunakan uji Chi-square dan dikatakan bermakna bila $\mathrm{p}<0.05$.

\section{HASIL}

Penelitian ini dilakukan pada 61 siswa yang berasal dari SDN 06 Pasir Jambak, SDN 23 Pasir Sebelah dan SDN 31 Pasir Kandang.

Tabel 1. Karakteristik subjek penelitian

\begin{tabular}{lcc}
\hline & $\mathbf{f}$ & $\%$ \\
\hline Jenis Kelamin & 26 & 42,6 \\
Laki-laki & 35 & 57,4 \\
Perempuan & & \\
Usia & 6 & 9,8 \\
$6-<7$ tahun & 20 & 32,8 \\
$7-<8$ tahun & 18 & 29,5 \\
$8-<9$ tahun & 11 & 18,0 \\
$9-<10$ tahun & 6 & 9,8 \\
$10-<11$ tahun & 6 \\
\hline
\end{tabular}

Berdasarkan Tabel 1 dapat dilihat bahwa jumlah responden berjenis kelamin laki-laki 42,6\% dan perempuan $57,4 \%$. Usia responden berada diantara 6 $<11$ tahun, dengan usia terbanyak adalah $7-<8$ tahun $(32,8 \%)$ dan paling sedikit adalah usia $6-<7$ dan 10 $<11$ tahun $(9,8 \%)$. 
Tabel 2. Gambaran infeksi STH berdasarkan status infeksi, jenis cacing, intensitas infeksi, jenis kelamin dan usia

\begin{tabular}{|c|c|c|}
\hline & $f$ & $\%$ \\
\hline \multicolumn{3}{|l|}{ Status infeksi } \\
\hline Infeksi + & 15 & 24,6 \\
\hline Infeksi - & 46 & 75,4 \\
\hline \multicolumn{3}{|l|}{ Jenis cacing } \\
\hline Ascaris lumbricoides (Al) & 4 & 26,7 \\
\hline Trichuris trichiura $(\mathrm{Tt})$ & 4 & 26,7 \\
\hline $\mathrm{Al}+\mathrm{Tt}$ & 7 & 46,7 \\
\hline \multicolumn{3}{|l|}{ Intensitas infeksi } \\
\hline \multicolumn{3}{|l|}{ Ascaris lumbricoides (AI) } \\
\hline Ringan & 2 & 13,3 \\
\hline Sedang & 2 & 13,3 \\
\hline \multicolumn{3}{|l|}{ Trichuris trichiura $(\mathrm{Tt})$} \\
\hline Ringan & 3 & 20.0 \\
\hline Sedang & 1 & 6,7 \\
\hline \multicolumn{3}{|l|}{$\mathrm{Al}+\mathrm{Tt}$} \\
\hline Ringan + Ringan & 1 & 6,7 \\
\hline Sedang + Ringan & 2 & 13,3 \\
\hline Sedang + Sedang & 4 & 26,7 \\
\hline \multicolumn{3}{|l|}{ Jenis Kelamin } \\
\hline Laki-laki & 8 & 53,3 \\
\hline Perempuan & 7 & 46,7 \\
\hline \multicolumn{3}{|l|}{ Usia } \\
\hline $6-<7$ tahun & 0 & 0 \\
\hline $7-<8$ tahun & 5 & 33,3 \\
\hline $8-<9$ tahun & 8 & 53,3 \\
\hline $9-<10$ tahun & 2 & 13,3 \\
\hline $10-<11$ tahun & 0 & 0 \\
\hline
\end{tabular}

Berdasarkan Tabel 2 dapat dilihat bahwa responden yang terinfeksi cacing adalah sebanyak 15 orang, dengan jenis cacing yang paling banyak menginfeksi yaitu campuran dari Ascaris lumbricoides dan Trichuris trichiura 46,7\%. Intensitas infeksi STH yang didapatkan berada pada derajat ringan - sedang. Dari jenis kelamin dapat dilihat bahwa anak laki-laki lebih banyak terinfeksi cacing dibanding anak perempuan dengan anak laki-laki sebanyak 53,3\% dan dan anak perempuan 46,7\%. Berdasarkan usia, anak-anak lebih banyak terinfeksi cacing dalam rentang usia $7-<9$ tahun.
Tabel 3. Gambaran kejadian atopi pada anak SD di wilayah kerja Puskesmas Lubuk Buaya

\begin{tabular}{lcc}
\hline & $\mathbf{f}$ & $\%$ \\
\hline Kejadian atopi & & \\
Atopi & 11 & 18,0 \\
Tidak atopi & 50 & 82,0 \\
\hline
\end{tabular}

Berdasarkan Tabel 3 dapat dilihat bahwa didapatkan responden atopi lebih sedikit dibandingkan responden yang tidak atopi.

Tabel 4. Hubungan antara infeksi STH dengan kejadian atopi pada anak SD di wilayah kerja Puskesmas Lubuk Buaya

\begin{tabular}{lccccccc}
\hline \multirow{2}{*}{$\begin{array}{l}\text { Status } \\
\text { infeksi }\end{array}$} & \multicolumn{4}{c}{ Kejadian atopi } & \multicolumn{2}{c}{ Total } & \multirow{2}{*}{ Nilai p } \\
\cline { 2 - 6 } & \multicolumn{2}{c}{ Atopi } & \multicolumn{2}{c}{ Tidak atopi } & & & \\
\cline { 2 - 6 } & $\mathbf{n}$ & $\%$ & $\mathbf{n}$ & $\%$ & $\mathbf{n}$ & $\%$ & \\
\hline Infeksi & 2 & 3,3 & 13 & 21,3 & 15 & 24,6 & \\
+ & & & & & & & 0,712 \\
Infeksi & 9 & 14,8 & 37 & 60,7 & 46 & 75,4 & \\
\hline & & & & & & & \\
\hline
\end{tabular}

Berdasarkan Tabel 4, hasil analisis bivariat antara kedua variabel tersebut didapatkan nilai $p=0,712$, karena nilai $p>0,05$ maka dapat disimpulkan bahwa tidak terdapat hubungan yang signifikan antara infeksi STH dengan kejadian atopi pada anak SD di wilayah kerja Puskesmas Lubuk Buaya.

\section{PEMBAHASAN}

\section{Gambaran infeksi STH pada anak SD di wilayah} kerja Puskesmas Lubuk Buaya

Berdasarkan pemeriksaan feses yang telah dilakukan terhadap 61 orang siswa, didapatkan siswa yang terinfeksi Soil Transmitted Helminth sebanyak 15 orang, dengan infeksi terbanyak adalah infeksi campuran antara A.lumbricoides dan T.trichiura (46,7\%), sedangkan infeksi tunggal dari A.lumbricoides dan T.trichiura masing-masing (26,7\%). Hal ini sama dengan penelitian yang dilakukan oleh Rahmadhani (2016) yang mendapatkan hasil bahwa prevalensi 
paling banyak yaitu campuran antara antara A.lumbricoides dan T.trichiura yaitu sebanyak $43,4 \%{ }^{15}$ Penelitian di SDN 23 Pasir Sebelah Kota Padang yang dilakukan oleh Maharani (2015) yang juga mendapatkan prevalensi paling banyak yaitu campuran antara antara A.lumbricoides dan T.trichiura sebanyak $23,1 \% .^{16}$

Lokasi penelitian berada di pinggir pantai, hal ini menjadi salah satu faktor yang menyebabkan tingginya angka kejadian infeksi oleh A.lumbricoides dan T.trichiura. Kondisi tanah pantai yang lembab dan juga suhu yang optimal mendukung perkembangan telur cacing. Telur $A$. lumbricoides membutuhkan suhu optimum $25^{\circ} \mathrm{C}-30^{\circ} \mathrm{C}$ dan telur $T$. trichiura membutuhkan suhu optimum $30^{\circ} .{ }^{17}$

Menurut hasil pemeriksaan, usia paling banyak terjadinya infeksi Soil Transmitted Helminth adalah berada pada usia 7-<9 tahun. Hasil ini sejalan dengan hasil penelitian yang didapatkan oleh Azika (2016) dengan hasil usia paling banyak ditemukan telur STH adalah kelompok usia 7-8 tahun. Hal ini dipengaruhi oleh perbedaan dari tingkat pengetahuan dan higiene perorangan, sehingga menyebabkan anak berusia 7-8 tahun lebih sering terinfeksi cacing dibandingkan dengan kelompok umur lainnya yang lainnya. ${ }^{18}$

Hasil penelitian menunjukkan kecendrungan terjadinya infeksi cacing pada anak laki-laki dibanding anak perempuan. Tingginya insidensi kecacingan pada anak laki-laki ini lebih dikarenakan adanya perbedaan dalam hal kebiasaan dan aktivitas siswa. Pada dasarnya, kecacingan yang terjadi pada setiap orang tidak membedakan jenis kelamin. ${ }^{19}$

\section{Gambaran kejadian atopi pada anak SD di wilayah kerja Puskesmas Lubuk Buaya}

Penelitian yang dilakukan pada anak SD ini didapatkan bahwa prevalensi anak yang mengalami atopi lebih rendah yaitu hanya $18 \%$ dibandingkan dengan yang tidak atopi sebesar $82 \%$. Hal ini sejalan dengan penelitian yang dilakukan oleh Garde et al (2009) yang juga melakukan penelitian atopi pada anak, dan didapatkan bahwa prevalensi anak yang menderita atopi yaitu sebesar $20 \% .{ }^{20}$ Berbeda dengan hal tersebut, penelitian yang dilakukan oleh Harminarti et al (2008) justru mendapatkan prevalensi anak yang mengalami atopi lebih besar daripada yang tidak mengalami atopi yaitu sebesar $70,2 \%{ }^{9}$

Terdapat beberapa faktor yang mempengaruhi terjadinya atopi diantaranya yaitu faktor genetik dan faktor lingkungan. Faktor lingkungan yang dapat mempengaruhi atopi yaitu paparan alergen yang tinggi, paparan hewan peliharaan dan hewan ternak, tingkat sosial ekonomi, status gizi dan faktor gaya hidup seperti diet, $\mathrm{ASI}$, dan ibu yang merokok. ${ }^{21}$

\section{Hubungan antara infeksi STH dengan kejadian atopi pada anak SD di wilayah kerja Puskesmas Lubuk Buaya}

Pada penelitian ini didapatkan bahwa tidak terdapat hubungan yang bermakna antara infeksi STH dengan kejadian atopi. Hasil penelitian ini sejalan dengan penelitian yang dilakukan oleh Andiarsa et al (2013) yang juga mendapatkan hasil bahwa tidak terdapat hubungan yang bermakna antara infeksi STH dengan kejadian atopi. ${ }^{14}$ Pada penelitian yang dilakukan oleh Harminarti et al (2008) juga tidak ditemukan adanya perbedaan yang bermakna prevalensi alergi pada subjek yang terinfeksi cacing dengan prevalensi alergi pada subjek yang tidak terinfeksi cacing. ${ }^{9}$

Hasil pada penelitian ini dipengaruhi oleh beberapa hal, salah satunya yaitu jenis cacing. Menurut Cooper (2009) perbedaan jenis cacing memiliki efek yang berbeda terhadap risiko atopi dan penyakit alergi. ${ }^{7}$ Pada penelitian ini jenis cacing yang didapatkan hanya A.lumbricoides dan T.trichiura, sedangkan infeksi cacing tambang tidak ditemukan. Penelitian oleh Scrivener et al (2001) di Ethiopia mendapatkan bahwa askariasis tidak menunjukkan adanya pengurangan alergi yang signifikan, sedangkan infeksi cacing tambang memperlihatkan adanya pengurangan alergi secara signifikan. ${ }^{22}$ Pada suatu penelitian yang juga dilakukan di Ethiopia, didapatkan bahwa terjadi penurunan bermakna terhadap sensitisasi tungau debu rumah pada orang dengan risiko asma yang terinfeksi cacing tambang, tetapi pada orang yang terinfeksi T.trichiura tetap menunjukkan angka sensitisasi yang tinggi. ${ }^{23}$

Pada studi meta-analisis yang dilakukan oleh Leonardi-Bee et al pada tahun 2006 untuk menyelidiki 
hubungan antara infeksi STH dengan kejadian atopi, menunjukkan bahwa efek infeksi cacing usus dalam menekan alergi tidak konsisten, tetapi infeksi cacing tambang memperlihatkan adanya efek proteksi terhadap alergi. Berdasarkan beberapa penelitian yang di analisis tersebut didapatkan bahwa infeksi cacing tambang memiliki proteksi alergi yang lebih kuat dibanding infeksi A.lumbricoides maupun T.trichiura. ${ }^{24}$ Infeksi cacing tambang juga telah terbukti dapat menekan respon host sel Th2 dengan sekresi metalloproteinase yang mencerna eotaxin, dengan induksi apoptosis pada limfosit $\mathrm{T}$, dan oleh sekresi calreticulin yang menonaktifkan $\mathrm{C} 1 \mathrm{q}$ dan respon inflamasi. ${ }^{25}$ Namun, pada penelitian ini tidak ditemukan adanya responden yang terinfeksi cacing tambang, sehingga peneliti tidak bisa melihat perbedaan efek prokteksi alergi pada infeksi A.lumbricoides, T.trichiura dan cacing tambang.

Intensitas infeksi juga mempengaruhi manifestasi alergi pada penderita yang terinfeksi cacing. Pada penelitian ini, didapatkan bahwa derajat infeksi responden berkisar antara derajat ringansedang, sedangkan derajat infeksi berat tidak ditemukan pada penelitian ini. Cooper (2009) menyatakan bahwa intensitas infeksi parasit yang berat dapat menginduksi modulasi respon imun tubuh sehingga dapat memproteksi individu yang terinfeksi cacing dari penyakit atopi, sedangkan infeksi ringan mungkin lebih cenderung memiliki efek sebaliknya. ${ }^{7} \mathrm{Hal}$ ini dapat dilihat bahwa pada penelitian hasil penelitian Dagoye et al (2003) yang mendapatkan pengurangan risiko alergi yang bermakna pada infeksi cacing tambang dengan intensitas tinggi. ${ }^{25}$ Intensitas infeksi kemungkinan mempengaruhi hasil penelitian ini menjadi tidak bermakna.

Pada penelitian ini tidak bisa ditentukan apakah infeksi yang terjadi merupakan infeksi akut ataupun kronis dikarenakan pengambilan sampel hanya satu waktu. Cooper (2009) menyebutkan bahwa lamanya infeksi berpengaruh terhadap manifestasi alergi pada penderita yang terinfeksi cacing. Pada infeksi akut, cacing dapat memicu peningkatan lgE sehingga mengaktifkan granulasi sel mast dan basofil yang nantinya akan mengeluarkan beberapa senyawa inflamasi seperti histamin, leukotrin, prostaglandin dan kemokin yang berdampak pada jaringan sekitarnya. Hal ini menyebabkan adanya responden yang terinfeksi cacing disertai dengan atopi. 7 Oleh karena itu, beberapa penelitian menunjukkan adanya peningkatan penyakit alergi pada populasi yang terinfeksi cacing, seperti yang terdapat pada penelitian yang dilakukan oleh Harminarti et al (2008). ${ }^{9}$

Pada infeksi yang terjadi secara kronis, cacing dapat memodulasi respon $\mathrm{lgE}$ dalam berbagai mekanisme, diantaranya yaitu mekanisme saturasi sel mast, penghambatan oleh lgG4 dan modikasi Th2. Hal ini akan menyebabkan terjadinya proteksi alergi pada individu yang terinfeksi cacing. $^{26} \mathrm{Hal}$ ini juga berhubungan dengan endemisitas infeksi cacing pada populasi yang berbeda. Daerah dengan prevalensi infestasi cacing yang rendah, yang bersifat sporadik maupun musiman memiliki gejala akut alergi yang lebih menonjol, sedangkan pada daerah dengan prevalensi infestasi cacing yang tinggi atau bersifat kronik dapat memproteksi individu dari respon alergi. ${ }^{21} \mathrm{Hal}$ ini sejalan dengan hasil penelitian di Venezuela, Gambia, Ethiopia, Taiwan, dan Ekuador yang melaporkan bahwa infeksi kronis dapat melindungi reaktivitas alergi. ${ }^{27}$

Pada penelitian ini, peneliti tidak menemukan adanya hubungan yang bermakna antara infeksi STH dengan alergi. Namun didapatkan bahwa individu yang mengalami atopi lebih banyak terdapat pada individu yang tidak terinfeksi cacing. Suatu penelitian yang pernah dilakukan pada individu dari daerah endemis yang diobati dengan obat antihelmentik umumnya menunjukkan peningkatan reaktivitas alergen pasca perawatan. Penelitian pada beberapa hewan coba oleh para ahli juga mendapatkan bahwa adanya efek proteksi terhadap gejala alergi. ${ }^{28}$

\section{SIMPULAN}

Infeksi Soil Transmitted Helminth (STH) yang cukup tinggi, dengan jenis infeksi terbanyak yaitu infeksi campuran antara A.lumbricoides dan T.trichiura. Untuk kejadian atopi, didapatkan angka kejadian yang lebih rendah dibandingkan dengan yang tidak atopi. Serta, tidak terdapat hubungan yang signifikan antara infeksi STH dengan kejadian atopi. 


\section{SARAN}

Pada penelitian selanjutnya, disarankan untuk melakukan pemeriksaan alergi yang lebih sensitif dan spesifik seperti tes uji kulit (Skin Prick Test), serta melakukan penelitian yang dapat membedakan efek infeksi cacing akut dan kronis terhadap penyakit atopi seperti dengan melakukan pemeriksaan sediaan hapus darah tepi untuk melihat kadar eosinofil, IL-8, dan IL-10.

\section{UCAPAN TERIMA KASIH}

Terima kasih kepada pihak Fakultas Kedokteran Universitas Andalas, Laboratorium Parasitologi Universitas Andalas, Puskesmas Lubuk Buaya Kota Padang, SD Negeri 06 Pasir Jambak, SD Negeri 31 Pasir Kandang, dan SD Negeri 23 Pasir Sebelah yang sudah membantu dalam mewadahi penelitian ini.

\section{DAFTAR PUSTAKA}

1. Dunn JC, Turner HC, Tun A, Anderson RM. Epidemiological surveys of, and research on, soiltransmitted helminths in Southeast Asia: A systematic review. Parasites and Vector. 2016;9:1-13.

2. Mardiana, Djarismawati. Prevalensi cacing usus pada murid sekolah dasar wajib belajar pelayanan gerakan terpadu pengentasan kemiskinan daerah kumuh di wilayah DKI Jakarta. Jurnal Ekologi Kesehatan. 2008;7:769-74.

3. World Health Organization (WHO). Soiltransmitted helminth infections. Geneva: WHO; 2018

4. Direktorat Jenderal Pengendalian Penyakit dan Penyehatan Lingkungan (Ditjen PPPL). Seminar pengembangan strategi pengendalian kecacingan dan perilaku CTPS di Indonesia. Jakarta: Departemen Kesehatan RI; 2012.

5. Dinas Kesehatan Kota (DKK) Padang. Data Infeksi cacing di kota Padang. Padang: DKK: 2014.

6. Darmadi D, Irawati N, Nasrul E. Perbandingan kadar IL-5 dan jumlah eosinofil antara anak dan orang dewasa yang terinfeksi Ascaris lumbricoides. Jurnal Kesehatan Andalas. 2015;4(3):756-64.
7. Cooper PJ. Interactions between helminth parasites and allergy. Allergy. 2009;9(1):29-37.

8. Baratawidjaja KG, Rengganis I. Alergi Dasar. Edisi ke-1. Jakarta: Interna Publishing Pusat Penerbitan IImu Penyakit Dalam; 2009.hlm.95-231.

9. Harminarti N, Supali T, Wibowo H. Hubungan infeksi cacing usus dan atopi pada anak sekolah dasar. Majalah Kedokteran Andalas. 2008;32(1):1.

10. Puskesmas Lubuk Buaya. Data penyakit atopi di Puskesmas Lubuk Buaya. 2018.

11. Yazdanbakhsh M, Kremsner PG, Van Ree R. Immunology: Allergy, parasites, and the hygiene hypothesis. Science. 2002;296(5567):490-4.

12. Sitcharungsi $R$, Sirivichayakul C. Allergic diseases and helminth infections. Pathogens and Global Health. 2013;107(3):110-5.

13. Andiarsa D. Infeksi cacing, imunitas dan alergi. Jurnal Buski. 2012;4(1):47-52.

14. Andiarsa D, Meliyanie G, Hidayat S. Alergi dan infeksi cacing pada anak Sekolah Dasar Negeri Kampung Baru Kecamatan Kusan Hilir Kabupaten Tanah Bumbu dengan status sosial ekonomi yang berbeda. Jurnal Buski. 2013;4(3):115-20.

15. Ramadhani A. Hubungan antara infeksi Soil Transmitted Helminths dengan status gizi pada siswa SDN 23 Pasir Sebelah Kota Padang [skripsi]. Padang: Fakultas Kedokteran, Universitas Andalas; 2016.

16. Maharani RR. Hubungan infeksi Soil Transmitted Helminth dengan status gizi pada murid SDN 29 Purus Padang [skripsi]. Padang: Fakultas Kedokteran, Universitas Andalas; 2015.

17. Supali T, Margono SS, Abidin SAN. Nematoda Usus. Dalam: Sutanto I, Ismid IS, Sjarifuddin PK, Sungkar $S$ (eds). Buku ajar parasitologi kedokteran. Edisi ke-4. Jakarta: Balai Penerbit FKUI; 2013.hlm.6-24.

18. Azika WN. Hubungan infeksi Soil Transmitted Helminth dengan status gizi pada siswa SDN 31 Pasir Kandang Kota Padang [skripsi]. Padang: Fakultas Kedokteran, Universitas Andalas; 2016.

19. Hairani B, Waris L, Juhairiyah. Risiko infeksi cacing usus pada anak sekolah dasar berdasarkan ekosistem yang berbeda di Kabupaten Tanah Bambu tahun 2009. Jurnal Buski. 2014;5(1):43-8. 
20. Garde J, Hervás D, Marco N, Milan JM, Martos MD. Allergologia et Calculating the prevalence of atopy in children. Allergologia et Immunopathologia. 2009;37(3):129-34.

21. Cooper PJ. Intestinal worms and human allergy. Parasite Immunology. 2004;26:455-67.

22. Scrivener $S$, Yemaneberhan $H$, Zebenigus $M$, Tilahun D, Girma S, Ali S, et al. Independent effects of intestinal parasite infection and domestic allergen exposure on risk of wheeze in Ethiopia: $A$ nested case-control study. Lancet. 2001; 358 (9292):1493-9.

23. Mangan NE, Rooijen N V, McKenzie ANJ, Fallon PG. Helminth-modified pulmonary immune response protects mice from allergen-induced airway hyperresponsiveness. The Journal of Immunology. 2006;176(1):138-47.

24. Leonardi-bee J, Pritchard D, Britton J. Asthma and current intestinal parasite infection systematic review and meta-analysis. American Journal of
Respiratory Critical Care Medicine. 2006;174:51423.

25. Dagoye D, Bekele Z, Woldemichael K, Nida H, Yimam $M$, Hall $A$, et al. Wheezing, allergy, and parasite infection in children in urban and rural ethiopia. American Journal of Respiratory Critical Care Medicine. 2003;167(10):1369-73.

26. Rusjdi SR. Infeksi Cacing dan Alergi. Jurnal Kesehatan Andalas. 2015;4(1):322-5.

27. Smits $\mathrm{HH}$, Everts B, Hartgers FC, Yazdanbakhsh M. Chronic helminth infections protect against allergic diseases by active regulatory processes. Current Allergy and Asthma Reports. 2010; 10 (1): 3-12.

28. Cooper PJ, Chico ME, Vaca MG, Sandoval CA, Loor S, Amorim LD, et al. Effect of early-life geohelminth infections on the development of wheezing at 5 years of age. American Journal of Respiratory Critical Care Medicine. 2018; 197 (3): 364-72. 